\title{
Risk factors for residual and recurrent uveal melanoma after trans-scleral local resection
}

\author{
Bertil E Damato, James Paul, Wallace S Foulds
}

\begin{abstract}
Aims-The aims of this study were to report local tumour control after transscleral local resection of uveal melanoma and to identify risk factors for (i) clinical residual tumour recognised immediately after surgery, and (ii) delayed tumour recurrence from subclinical microscopic deposits.
\end{abstract}

Methods-The sample included 310 patients, treated by choroidectomy (188), cyclochoroidectomy (87), or iridocyclectomy (35), with follow up ranging from 42 days to 20.9 years (median 36 months), a mean basal largest tumour diameter of $13.2 \mathrm{~mm}$, and a mean tumour thickness of $7.4 \mathrm{~mm}$.

Results-There were 24 patients with residual tumour. Forward stepwise logistic regression indicated that posterior extension to within 1 disc diameter of the optic disc or fovea was the sole best indicator of the risk of residual disease $(\mathbf{p}<0 \cdot 001)$. After excluding these cases, 286 patients were studied for the development of delayed local recurrence, which occurred in 57 cases. Forward stepwise multivariate analysis showed the statistically significant predictors for recurrent tumour to be epithelioid cellularity $(p=0.002)$, posterior tumour extension to $<1$ disc diameter of disc of fovea $(p=0.002)$, large tumour diameter $\geqslant 16$ mm $(p=0.019)$ and lack of adjunctive plaque radiotherapy $(p=0 \cdot 018)$.

Conclusions-The recurrence rate at 4 years varied from $6 \%$ if no risk factors were present to $57 \%$ if there were more than two risk factors.

(Br f Ophthalmol 1996; 80: 102-108)

Tennent Institute of Ophthalmology, Western Infirmary, University of Glasgow B E Damato W S Foulds

Clinical Trials Unit, Beatson Oncology Centre, Western Infirmary, Glasgow J Paul

Correspondence to: Mr Bertil E Damato, Ocular Oncology Service, St Paul's Eye Unit, Royal Liverpool University Hospital, Presco Street, Liverpool L7 8XP.

Accepted for publication 11 August 1995 was enucleation, but now there is increasing interest in conserving the eye and vision by a variety of methods, which include brachytherapy, ${ }^{2-4}$ teletherapy, ${ }^{4-6}$ and trans-scleral local resection..$^{7-9}$ Trans-scleral local resection is technically difficult and is, therefore, performed in only a few centres, where it is reserved for tumours that are deemed to be unsuitable for plaque or proton beam radiotherapy. ${ }^{10}$ Previous studies show that conservation of the eye and vision is possible when a choroidal tumour does not extend very close to optic disc or fovea, ${ }^{11}$ and when a ciliary body tumour is small. ${ }^{12}$ One of the main complications of trans-scleral local resection is incomplete tumour removal, which manifests either immediately as visible residual tumour at the end of the operation or after a delay of months or years when recurrent tumour arises from invisible microscopic tumour deposits. Residual and recurrent tumours after transscleral local resection follow retinal detachment as the commonest causes of visual loss and enucleation ${ }^{11}$ and are also associated with an increased incidence of metastasis. ${ }^{13}$ The aims of this study were to identify the risk factors for clinical residual tumour and delayed tumour recurrence so that these complications might be avoided.

\section{Patients, materials, and methods}

\section{PREOPERATIVE ASSESSMENT}

Our methods of preoperative assessment are described elsewhere. ${ }^{1011}$ The following data were obtained at the time of treatment or subsequently by reviewing photographs and records: (i) patient age and sex; (ii) Snellen visual acuity measured with spectacles, pinhole, or unaided as clinically indicated; (iii) tumour height and largest and smallest basal tumour diameters as measured by B-scan ultrasonography; (iv) location of anterior and posterior margins of the tumour; and (v) coronal and sagittal location of the tumour. The tumour was said to have 'posterior tumour extension' if its posterior margin was situated within 1 disc diameter of the disc margin or fovea. The coronal location of the tumour was categorised as 'vertical' if the 'centre of gravity' of the tumour was located on a vertical line passing through the fovea, and 'nasal' or 'temporal' if the tumour was placed medial or lateral to the fovea.
The surgical techniques are described in detail elsewhere. ${ }^{10}$ Briefly, a rectangular lamellar scleral flap was dissected over the tumour, after defining the tumour margins by
SURGICAL TECHNIQUE 
transpupillary transillumination. The deep sclera and choroid were divided some 3-5 mm from the tumour, which was removed avoiding retinal damage whenever possible. Since 1986, partial ocular decompression was routinely performed, either before the dissection of the scleral flap by three port vitrectomy (WSF), or after preparation of the flap via a single sclerotomy and without infusion (BED). Haemorrhage was minimised by lowering the systolic blood pressure to approximately 40-60 mm Hg. ${ }^{14}$ The sclera was closed with interrupted 8-0 virgin silk, nylon, or vicryl sutures. Any small extraocular tumour nodule was excised with a surround of full thickness sclera and the defect in the lamellar flap was closed with a lamellar graft taken from a healthy part of the same eye. Adjunctive plaque radiotherapy was applied routinely (that is, as often as possible) between the years of 1986 and 1989, but before and after this period such radiotherapy was administered only if there was definite or probable residual tumour. A ruthenium plaque was used, except in five cases treated before 1981, when only a cobalt plaque was available. External plombage and/or internal tamponade with gas or silicone were used to prevent retinal detachment if a large retinal defect was created.

\section{PATHOLOGICAL EXAMINATION}

Tumours were categorised as spindle cell, mixed, or epithelioid but the latter two types were considered together for this study because of the small number of purely epithelioid tumours. Surgical clearance was considered adequate if normal choroid was present

Table 1 Residual tumour after local resection

\begin{tabular}{|c|c|c|c|c|}
\hline Variable & Categories & $\begin{array}{l}\text { Number } \\
\text { of } \\
\text { patients }\end{array}$ & $\begin{array}{l}\text { Percentage } \\
\text { with residual } \\
\text { disease }\end{array}$ & $p$ Value \\
\hline Sex & $\begin{array}{l}\text { Female } \\
\text { Male }\end{array}$ & $\begin{array}{l}154 \\
156\end{array}$ & $\begin{array}{r}5 \\
10\end{array}$ & 0.095 \\
\hline Age at diagnosis (years) & $\begin{array}{l}\leqslant 39 \\
\quad 40-60 \\
>60\end{array}$ & $\begin{array}{r}64 \\
162 \\
84\end{array}$ & $\begin{array}{l}8 \\
9 \\
6\end{array}$ & 0.755 \\
\hline Eye & $\begin{array}{l}\text { Right } \\
\text { Left }\end{array}$ & $\begin{array}{l}134 \\
176\end{array}$ & $\begin{array}{l}7 \\
8\end{array}$ & 0.872 \\
\hline Initial vision & $\begin{array}{l}6 / 6-6 / 12 \\
6 / 18-6 / 36 \\
6 / 60 \text { or worse }\end{array}$ & $\begin{array}{r}179 \\
74 \\
57\end{array}$ & $\begin{array}{r}7 \\
8 \\
11\end{array}$ & 0.637 \\
\hline Anterior tumour margin & $\begin{array}{l}\text { Posterior to ora serrata } \\
\text { Anterior to ora serrata }\end{array}$ & $\begin{array}{l}152 \\
158\end{array}$ & $\begin{array}{r}12 \\
4\end{array}$ & 0.008 \\
\hline Posterior tumour margin & $\begin{array}{l}<1 \text { DD from disc or fovea } \\
\geqslant 1 \text { DD from disc or fovea }\end{array}$ & $\begin{array}{r}38 \\
272\end{array}$ & $\begin{array}{r}26 \\
5\end{array}$ & $<0.001$ \\
\hline Coronal tumour position & $\begin{array}{l}\text { Nasal to fovea } \\
\text { Vertical midline } \\
\text { Temporal to fovea }\end{array}$ & $\begin{array}{r}123 \\
38 \\
149\end{array}$ & $\begin{array}{r}11 \\
5 \\
6\end{array}$ & 0.315 \\
\hline Sagittal tumour position & $\begin{array}{l}\text { Superior to fovea } \\
\text { Horizontal meridian } \\
\text { Inferior to fovea }\end{array}$ & $\begin{array}{r}111 \\
63 \\
136\end{array}$ & $\begin{array}{r}10 \\
6 \\
7\end{array}$ & 0.565 \\
\hline Operation type & $\begin{array}{l}\text { Choroidectomy } \\
\text { Cyclochoroidectomy } \\
\text { Iridocyclectomy }\end{array}$ & $\begin{array}{r}188 \\
87 \\
35\end{array}$ & $\begin{array}{r}11 \\
3 \\
3\end{array}$ & 0.060 \\
\hline Year of operation & $\begin{array}{l}\leqslant 1985 \\
>1985\end{array}$ & $\begin{array}{l}142 \\
168\end{array}$ & $\begin{array}{r}10 \\
6\end{array}$ & $0 \cdot 200$ \\
\hline Ocular decompression & $\begin{array}{l}\text { No } \\
\text { Yes }\end{array}$ & $\begin{array}{l}163 \\
147\end{array}$ & $\begin{array}{l}9 \\
8\end{array}$ & 0.557 \\
\hline $\begin{array}{l}\text { Tumour thickness (mm) } \\
\text { (pathology measurement)* }\end{array}$ & $\begin{array}{l}<5 \\
5-8 \\
>8\end{array}$ & $\begin{array}{r}49 \\
143 \\
98\end{array}$ & $\begin{array}{l}8 \\
8 \\
5\end{array}$ & 0.603 \\
\hline $\begin{array}{l}\text { Tumour diameter (mm) } \\
\text { (pathology measurement) } t\end{array}$ & $\begin{array}{l}<11 \\
11-15 \\
>15\end{array}$ & $\begin{array}{r}66 \\
165 \\
70\end{array}$ & $\begin{array}{l}9 \\
9 \\
3\end{array}$ & $0 \cdot 228$ \\
\hline Cell type & $\begin{array}{l}\text { Spindle } \\
\text { Mixed/epithelioid }\end{array}$ & $\begin{array}{l}184 \\
126\end{array}$ & $\begin{array}{l}9 \\
6\end{array}$ & 0.448 \\
\hline
\end{tabular}

^Pathological height not recorded for 20 patients; tpathological diameter not recorded for nine patients. beyond the tumour margin, uncertain if tumour extended close to the excision edge, and inadequate if tumour was present at the resection edge.

\section{PATIENT FOLLOW UP}

After the local resection, patients were reviewed after 1 month, 6 months, and then annually, if possible, unless more frequent visits were indicated because of complications. The following data were recorded: (i) visual acuity, measured with a Snellen chart either unaided, or with current spectacles, or pinhole as appropriate; and (ii) ocular and systemic complications together with the date of their diagnosis. Residual tumour and recurrent tumours were categorised as 'possible' when pigmentation could not be differentiated from retinal pigment epithelial hyperplasia and 'definite' when the diagnosis was certain. During most of the study, postoperative low energy, long duration laser photocoagulation ${ }^{15}$ was applied only to 'possible' or 'definite' residual and recurrent tumours, whereas in the latter part of the study a double row of confluent photocoagulation burns was routinely applied to margins of the coloboma in all patients irrespective of whether or not residual tumour was suspected.

\section{STATISTICAL METHODS}

During the 18 months preceding the close of the study or the date of death, follow up data were obtained on $96 \%$ of all the 250 live patients, with all patients lost to follow up living overseas. The data were derived from examinations performed by one of the clinical authors (BED or WSF) or by the referring ophthalmologists, who returned questionnaires.

Residual tumour was defined as any clinical tumour diagnosed in the first 40 postoperative days. The time period of 40 days was selected because in some patients the fundus could not be examined until the first postoperative visit, which was usually about 1 month after the operation. Recurrent tumour was defined as any clinical tumour diagnosed more than 40 days after apparently complete tumour resection.

Pearson's $\chi^{2}$ test was used to identify important associations between presence of residual tumour and various individual prognostic factors. Logistic regression ${ }^{16}$ was then used together with a forward stepwise procedure $(p$ to enter $=p$ to remove $=0.05)$ to identify factors which jointly predict for the presence of residual tumour. A backward stepwise procedure was also carried out, giving the same model as the forward procedure, and therefore is not referred to specifically in the results section.

In relation to recurrent tumour, $\mathrm{p}$ values for the univariate comparisons of time to recurrent tumour between different groups were derived by fitting Cox's proportional hazards model ${ }^{17}$ to the data. A forward stepwise procedure ( $p$ to enter $=p$ to remove $=0.05$ ) was used in conjunction with Cox's proportional hazards 
model to identify those factors influencing tumour recurrence most profoundly. Again, a backward stepwise procedure was also carried out and gave the same model as the forward procedure; therefore, this is not referred to specifically in the results section. KaplanMeier estimates ${ }^{16}$ were used to draw survival curves of time to recurrence. As with the outcome of any statistical analysis, the findings presented should be interpreted critically taking into account both the statistical and clinical levels of significance. Such caution is all the more necessary with stepwise procedures as they produce exaggerated $\mathrm{p}$ values.

Patients were included in the study if they had primary choroidectomy, cyclochoroidectomy (with or without iridectomy), or iridocyclectomy and a minimum follow up of 40 days to allow adequate time to assess whether or not patients had residual disease. They were excluded from the study if the operation was abandoned in favour of another form of conservative therapy or enucleation.

\section{Results}

SAMPLE

The study included 310 patients (154 female; 156 male; mean age: 51 years (SD 13.4)) (Table 1). The follow up for living patients varied from 42 days to 20 years 10 months, with a median of 36 months. The tumour margin extended anterior to the ora serrata in 158 patients and less than 1 disc diameter from the disc or fovea in 38 patients. The type of surgery was choroidectomy (occasionally with excision of part of the pars plicata of the ciliary body) in 188 patients, iridocyclochoroidectomy in 87 patients, and iridocyclectomy in 35 patients. Ocular decompression by pars plana vitrectomy was performed in 147 patients. Forty eight patients received adjunctive plaque radiotherapy. Pathological examination showed the largest tumour diameter to have a mean value of 13.2 (SD $4 \cdot 1$ ) $\mathrm{mm}$ and the tumour height to have a mean of $7.4(S D 3.0) \mathrm{mm}$. Epithelioid tumour cells were present in 126 patients.

\section{Predictive factors}

There were 24 patients (8\%) with residual tumour. The variables associated with an increased incidence of residual tumour were (i) posterior tumour extension $(\mathrm{p}<0.001)$, and (ii) anterior tumour margin located behind the ora serrata $(p=0.008)$. Forward stepwise logistic regression indicated that the only significant indicator of the risk of residual disease was posterior tumour extension (Table 1).

\section{Outcome}

In the 24 patients with residual tumour, the eye was retained in 17 patients and enucleated in seven patients, either primarily (one) or after unsuccessful conservative treatment. The initial treatment for residual tumour consisted of laser photocoagulation (16), plaque radiotherapy (six), photocoagulation and cryotherapy (one), and enucleation (one). Of the 16 patients receiving primary photocoagulation, seven did not have any further evidence of active tumour and nine required other treatment, which

Table 2 Recurrent tumour after local resection. Univariate analysis

\begin{tabular}{|c|c|c|c|c|c|c|}
\hline \multirow[b]{2}{*}{ Variable } & \multirow[b]{2}{*}{ Categories } & \multirow[b]{2}{*}{$\begin{array}{l}\text { No of } \\
\text { patients }\end{array}$} & \multirow[b]{2}{*}{$\begin{array}{l}\text { Relative } \\
\text { recurrence rate }\end{array}$} & \multicolumn{2}{|c|}{$95 \%$ Confidence interval for $R R$} & \multirow[b]{2}{*}{ p Value } \\
\hline & & & & $\begin{array}{l}\text { Lower } \\
\text { limit }\end{array}$ & $\begin{array}{l}\text { Upper } \\
\text { limit }\end{array}$ & \\
\hline Sex & $\begin{array}{l}\text { Female } \\
\text { Male }\end{array}$ & $\begin{array}{l}146 \\
140\end{array}$ & $\begin{array}{l}1.00 \\
1.47\end{array}$ & $\overline{0} \cdot 87$ & $\overline{2} \cdot 49$ & $0 \cdot 148$ \\
\hline Age at diagnosis (years) & $\begin{array}{l}<40 \\
\quad 40-60 \\
>60\end{array}$ & $\begin{array}{r}59 \\
148 \\
79\end{array}$ & $\begin{array}{l}1.00 \\
1.44 \\
2.05\end{array}$ & $\begin{array}{l}- \\
0 \cdot 66 \\
0.90\end{array}$ & $\begin{array}{l}3 \cdot 15 \\
4 \cdot 68\end{array}$ & $0 \cdot 200$ \\
\hline Eye & $\begin{array}{l}\text { Right } \\
\text { Left }\end{array}$ & $\begin{array}{l}124 \\
162\end{array}$ & $\begin{array}{l}1.00 \\
0.95\end{array}$ & $\overline{0} \cdot 56$ & $\overline{1.61}$ & 0.859 \\
\hline Initial vision & $\begin{array}{l}6 / 6-6 / 12 \\
6 / 18-6 / 36 \\
6 / 60 \text { or worse }\end{array}$ & $\begin{array}{r}167 \\
68 \\
51\end{array}$ & $\begin{array}{l}1 \cdot 00 \\
0 \cdot 87 \\
0.95\end{array}$ & $\begin{array}{l}0.45 \\
0.48\end{array}$ & $\begin{array}{l}-6 \\
1 \cdot 68 \\
1 \cdot 87\end{array}$ & 0.915 \\
\hline $\begin{array}{l}\text { Anterior tumour margin } \\
\text { (in relation to ora serrata) }\end{array}$ & $\begin{array}{l}\text { Posterior } \\
\text { Anterior }\end{array}$ & $\begin{array}{l}134 \\
152\end{array}$ & $\begin{array}{l}1 \cdot 00 \\
0.62\end{array}$ & $\overline{0} \cdot 37$ & 1.05 & 0.073 \\
\hline $\begin{array}{l}\text { Posterior tumour margin } \\
\text { (in relation to disc or fovea) }\end{array}$ & $\begin{array}{l}\geqslant 1 \text { DD } \\
<1 \text { DD }\end{array}$ & $\begin{array}{r}258 \\
28\end{array}$ & $\begin{array}{l}1 \cdot 00 \\
2 \cdot 57\end{array}$ & $\overline{1} \cdot 30$ & $\overline{5} .09$ & 0.005 \\
\hline Coronal tumour position & $\begin{array}{l}\text { Nasal to fovea } \\
\text { Vertical midline } \\
\text { Temporal to fovea }\end{array}$ & $\begin{array}{r}110 \\
36 \\
140\end{array}$ & $\begin{array}{l}1.00 \\
2.77 \\
1.95\end{array}$ & $\begin{array}{l}1.23 \\
1.05\end{array}$ & $\begin{array}{l}6 \cdot 24 \\
3 \cdot 65\end{array}$ & 0.028 \\
\hline Sagittal tumour position & $\begin{array}{l}\text { Superior to fovea } \\
\text { Horizontal meridian } \\
\text { Inferior to fovea }\end{array}$ & $\begin{array}{r}100 \\
59 \\
127\end{array}$ & $\begin{array}{l}1 \cdot 00 \\
1 \cdot 09 \\
1 \cdot 10\end{array}$ & $\begin{array}{l}- \\
0.52 \\
0.61\end{array}$ & $\begin{array}{l}- \\
6 \cdot 24 \\
3 \cdot 65\end{array}$ & 0.028 \\
\hline Operation type & $\begin{array}{l}\text { Iridocyclectomy } \\
\text { Choroidectomy } \\
\text { Cyclochoroidectomy }\end{array}$ & $\begin{array}{r}34 \\
84 \\
168\end{array}$ & $\begin{array}{r}1 \cdot 00 \\
10 \cdot 75 \\
10 \cdot 26\end{array}$ & $\begin{array}{l}- \\
1.47 \\
1.38\end{array}$ & $\begin{array}{r}78 \cdot 60 \\
76 \cdot 48\end{array}$ & 0.014 \\
\hline Adjunctive brachytherapy & $\begin{array}{l}\text { No } \\
\text { Yes }\end{array}$ & $\begin{array}{r}240 \\
46\end{array}$ & $\begin{array}{l}1.00 \\
0 \cdot 28\end{array}$ & $\overline{0.09}$ & $\overline{0.89}$ & 0.021 \\
\hline Ocular decompression & $\begin{array}{l}\text { No } \\
\text { Yes }\end{array}$ & $\begin{array}{l}149 \\
137\end{array}$ & $\begin{array}{l}1.00 \\
1.02\end{array}$ & 0.58 & $\overline{1} \cdot 79$ & 0.958 \\
\hline $\begin{array}{l}\text { Surgical clearance (on } \\
\text { histology) }\end{array}$ & $\begin{array}{l}\text { Yes } \\
\text { Uncertain } \\
\text { No }\end{array}$ & $\begin{array}{r}112 \\
37 \\
137\end{array}$ & $\begin{array}{l}1 \cdot 00 \\
1 \cdot 12 \\
1 \cdot 37\end{array}$ & $\begin{array}{l}- \\
0 \cdot 47 \\
0.78\end{array}$ & $\begin{array}{l}2 \cdot 66 \\
2 \cdot 43\end{array}$ & 0.538 \\
\hline $\begin{array}{l}\text { Tumour thickness (mm) } \\
\text { (pathology measurement) }\end{array}$ & $\begin{array}{l}<5 \\
5-8 \\
>8\end{array}$ & $\begin{array}{r}45 \\
131 \\
93\end{array}$ & $\begin{array}{l}1 \cdot 00 \\
2 \cdot 36 \\
1 \cdot 86\end{array}$ & $\begin{array}{l}- \\
0.92 \\
0.69\end{array}$ & $\begin{array}{l}-9.0 \\
6 \cdot 05 \\
5 \cdot 00\end{array}$ & $0 \cdot 172$ \\
\hline $\begin{array}{l}\text { Tumour diameter (mm) } \\
\text { (pathology measurement) } \dagger\end{array}$ & $\begin{array}{l}<11 \\
11-15 \\
>15\end{array}$ & $\begin{array}{r}60 \\
150 \\
68\end{array}$ & $\begin{array}{l}1 \cdot 00 \\
1 \cdot 97 \\
3.42\end{array}$ & $\begin{array}{l}\overline{0} \cdot 87 \\
1 \cdot 45\end{array}$ & $\begin{array}{l}\overline{4} \cdot 51 \\
8 \cdot 07\end{array}$ & 0.009 \\
\hline Cell type & $\begin{array}{l}\text { Spindle } \\
\text { Mixed/epithelioid }\end{array}$ & $\begin{array}{l}168 \\
118\end{array}$ & $\begin{array}{l}1 \cdot 00 \\
2 \cdot 47\end{array}$ & $\overline{1} \cdot 45$ & $\overline{4} \cdot 20$ & 0.001 \\
\hline
\end{tabular}

^Pathological height not recorded for 17 patients; tpathological diameter not recorded for eight patients. 


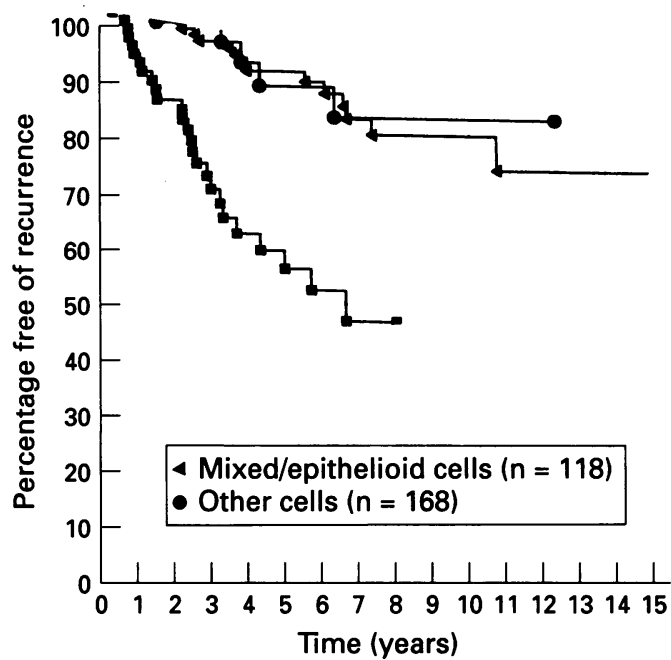

Figure 1 Kaplan-Meier curves showing the percentage of eyes without recurrent tumour according to tumour cell type. Local recurrence was more common with mixed and epithelioid tumours than with spindle cell tumours.

consisted of enucleation (five), plaque radiotherapy (three), or transretinal endoresection (one). The primary plaque radiotherapy was delivered either at the time of the local resection (two) or subsequently (four), with four of the six eyes requiring further treatment consisting of enucleation (one), photocoagulation (one), combined photocoagulation, second plaque and cryotherapy (one), and combined cryotherapy and photocoagulation (one). Two patients were found to have extraocular extension at the time of enucleation for unsuccessful photocoagulation.

\section{RECURRENT TUMOUR}

\section{Sample}

After excluding 24 patients with residual tumour, there were 286 patients available for analysis (146 female; 140 male; mean age 51 years; SD 13) (Table 2). The tumour extended anterior to the ora in 152 eyes and within 1 disc diameter of the disc or fovea in 28 eyes. The type of operation was choroidectomy in 84

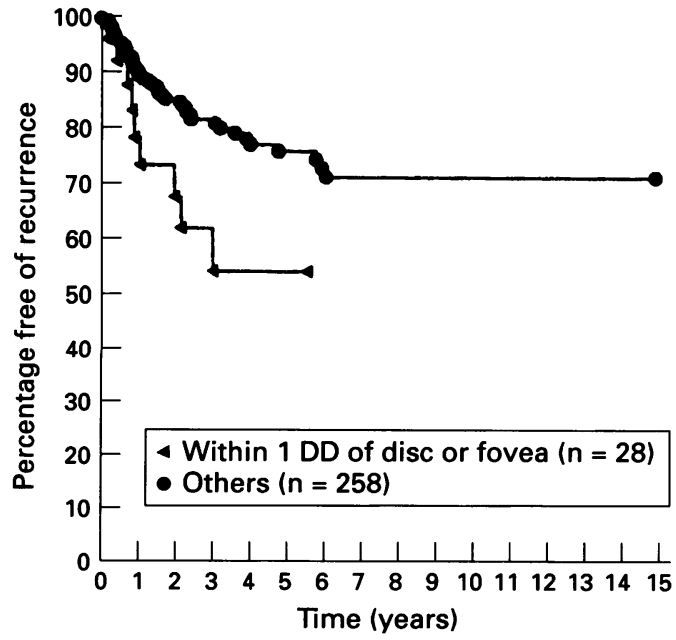

Figure 2 Kaplan-Meier curves showing the percentage of eyes without recurrent tumour according to posterior tumour extension. Local tumour recurrence was more likely when the tumour extended to within 1 disc diameter of the disc or fovea.

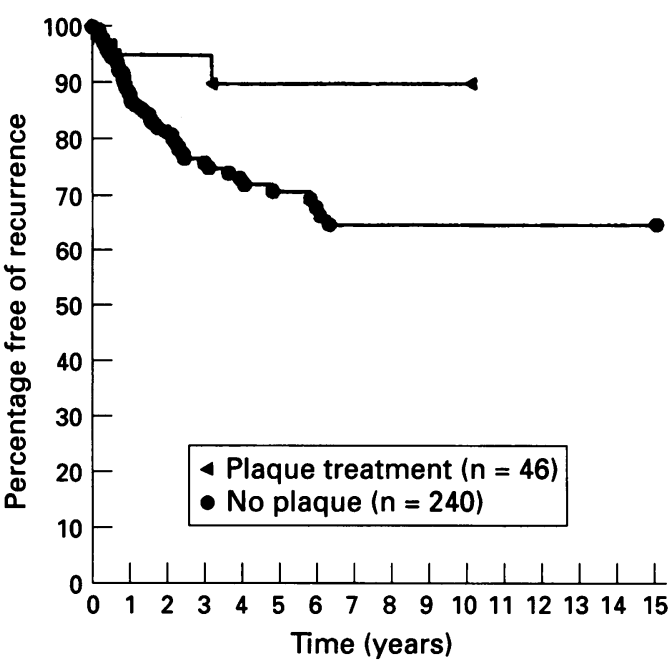

Figure 3 Kaplan-Meier curves showing the percentage of eyes without recurrent tumour according to adjunctive plaque radiotherapy. Local tumour recurrence was less likely after adjunctive plaque treatment.

patients, iridocyclochoroidectomy in 168 eyes, and iridocyclectomy in 34 eyes. Ocular decompression was performed in 137 eyes. Adjunctive plaque radiotherapy was applied in 46 patients.

Histopathological examination showed epithelioid cells in 118 tumours. The largest basal diameter had a mean of 13.2 (SD 4) $\mathrm{mm}$ and the thickness averaged 7.5 (SD 3.0) $\mathrm{mm}$. Clearance was uncertain in 37 eyes and inadequate in 137 eyes.

\section{Predictive factors}

Fifty seven eyes developed delayed tumour recurrence. Univariate analysis showed that the variables predicting recurrent tumour were (i) epithelioid cell type $(p=0.001)$, (ii) posterior tumour extension $(p=0.005)$, (iii) large tumour diameter $(p=0.009)$, (iv) tumour excisions involving choroid (that is, choroidectomy and iridocyclochoroidectomy) $(p=0.014)$, and (v) absence of adjunctive plaque radiotherapy $(p=0.021)$ (Table 2). Figures 1-4 show the Kaplan-Meier curves giving an indication of the

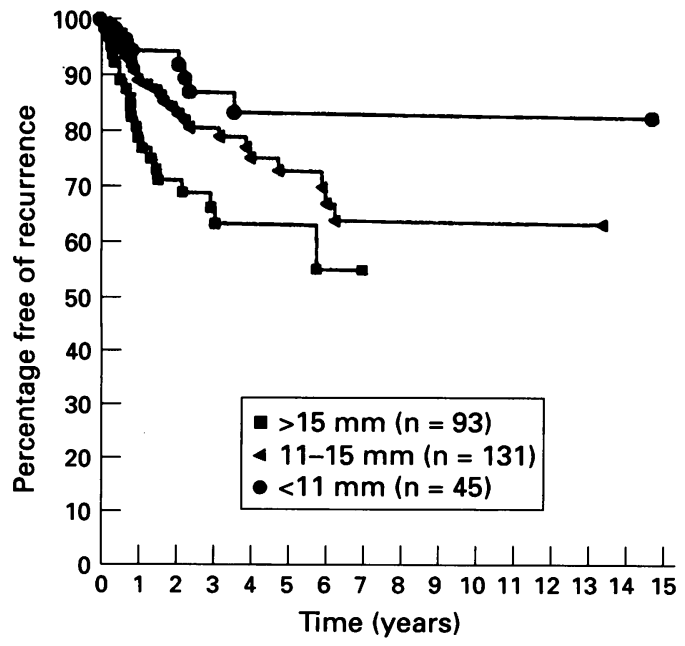

Figure 4 Kaplan-Meier curves showing the percentage of eyes without recurrent tumour according to largest tumour diameter. Local tumour recurrence was more likely with large tumours. 
Table 3 Recurrent tumour after local resection. Multivariate analysis

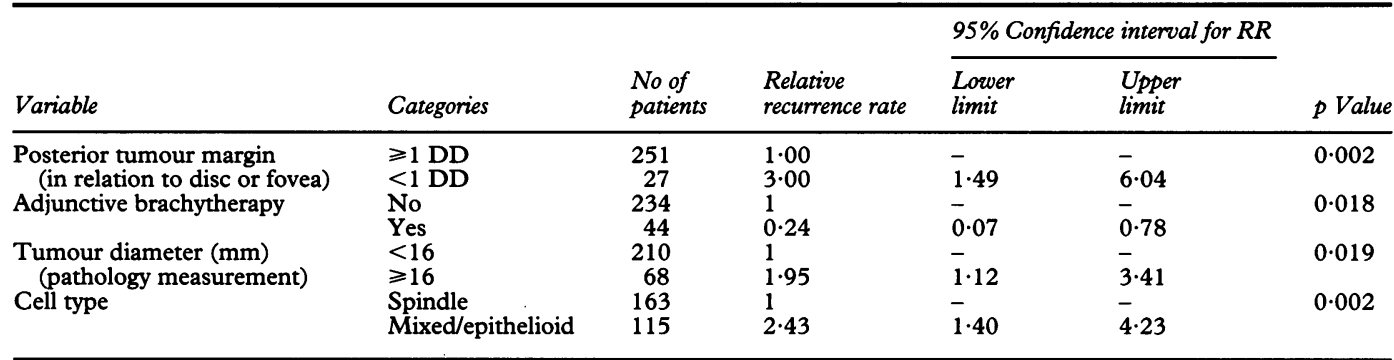

Total number of patients is 278 because pathological diameter was not recorded for eight patients.

times to tumour recurrence according to cell type, posterior tumour extension, plaque radiotherapy, and tumour diameter.

A forward stepwise selection procedure indicated in a multivariate setting that the statistically significant predictors for recurrent tumour were (i) epithelioid cellularity $(p=0.002)$, (ii) posterior tumour extension $(\mathrm{p}=0.002)$, (iii) large tumour diameter $(\mathrm{p}=0.019)$, and (iv) lack of plaque radiotherapy $(p=0.018)$ (Table 3). Each of these factors was given a score of +1 and patients were allocated into risk groups according to the sum of their risk factors. Figure 5 shows the Kaplan-Meier survival curves which give the time to recurrent tumour according to the risk group. The incidence and the rate of appearance of recurrent tumour were related to the number of risk factors. In the absence of any risk factors, $94 \%$ of patients were free of local tumour recurrence 4 years postoperatively. When one risk factor was present, this figure fell to $86 \%$ and when three or four risk factors were present about $43 \%$ of patients were free of recurrent disease 3 years postoperatively.

\section{Location}

The recurrent tumours were nearly all located within or at the margin of the surgical coloboma. In addition, intraocular metastases in distant parts of the eye were noted in nine patients. Sixteen eyes developed extraocular tumour extension.

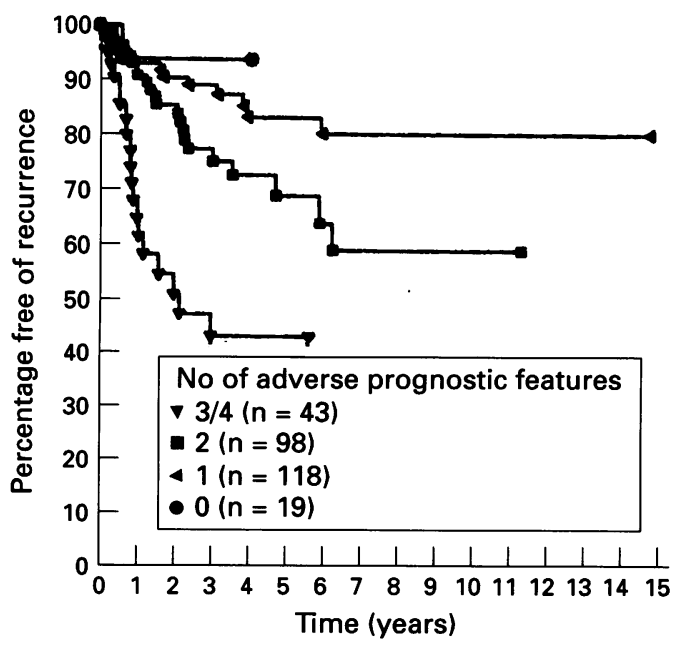

Figure 5 Kaplan-Meier curves showing the percentage of eyes without recurrent tumour according to the number of adverse prognostic features. Local tumour recurrence increased with the number of adverse features.

\section{Outcome}

Of the 57 patients with recurrent tumour, 27 $(47 \%)$ retained the eye at the close of the study, after receiving secondary plaque radiotherapy (six), photocoagulation (nine), photocoagulation and radiotherapy (10), cryotherapy, photocoagulation, and plaque (one), photocoagulation and endoresection (one). Twenty eight eyes were enucleated and one was exenterated. Loss of the eye occurred either in the first instance (15) or after further conservative treatment, which consisted of photocoagulation (seven), radiotherapy (two), photocoagulation and radiotherapy (two), cryotherapy photocoagulation and plaque (two), and a second local resection (one). Eleven patients received orbital irradiation for extraocular tumour extension.

Table 4 shows the vision at the last patient visit according to residual tumour, recurrent tumour, and retinal detachment. In the absence of any of these complications, $97 \%$ of 174 eyes were retained, with $83 \%$ of eyes having vision of counting fingers or better, and $35 \%$ having vision of $6 / 12$ or better. In the presence of persistent tumour and retinal detachment, then only $45 \%$ of eyes were retained, with none having vision better than $6 / 36$. When only one type of complication occurred, the $50-60 \%$ of eyes were retained, with preservation of vision being more successful after treatment of intraocular tumour than after retinal detachment surgery. In the 81 patients with residual or recurrent tumour the rate of metastatic death was $27 \%$ compared with $13 \%$ in 229 patients without these complications. Survival in all cases and visual outcome after choroidectomy are reported separately in other studies, ${ }^{11} 13$ with evaluation of visual outcome after cyclectomy still in progress.

\section{Discussion}

This is the largest study of residual and

Table 4 Vision at final visit according to residual recurrent tumour and retinal detachment

\begin{tabular}{lccccc}
\hline & \multicolumn{2}{l}{ Complications } & \multirow{2}{*}{ Total } \\
\cline { 2 - 5 } Visual acuity & Nil & Tumour & Detachment & Both & No \\
\hline Number & 174 & 61 & 55 & 20 & 310 \\
$6 / 6-6 / 12$ & $35 \%$ & $13 \%$ & $2 \%$ & $0 \%$ & $23 \%$ \\
$6 / 18-6 / 36$ & $21 \%$ & $13 \%$ & $9 \%$ & $0 \%$ & $16 \%$ \\
$6 / 60-$ CF & $27 \%$ & $28 \%$ & $18 \%$ & $20 \%$ & $25 \%$ \\
HM-NPL & $14 \%$ & $5 \%$ & $14 \%$ & $25 \%$ & $15 \%$ \\
Enucleated & $3 \%$ & $40 \%$ & $47 \%$ & $55 \%$ & $22 \%$ \\
\hline
\end{tabular}

$\mathrm{CF}=$ counting finger; $\mathrm{HM}=$ hand movements $\mathrm{NPL}=$ no perception of light. 
recurrent uveal melanoma after local resection yet reported, both in terms of number of patients and duration of follow up. The sample includes patients who were treated as early as 1969 before ruthenium plaque radiotherapy, laser photocoagulation, and vitrectomy were available to us, and before the treatment of retinal detachment had reached its present state of development. Furthermore, this sample includes patients operated on during the learning curves of two surgeons, in many cases with surgical techniques that have since been discontinued. For these reasons, the results reported in this study may not be representative of those that can now be achieved. Nevertheless, this study is useful because it identifies the risk factors for residual and recurrent disease so that appropriate preventive measures can be taken.

The overall incidence of clinical residual tumour was $8 \%$. Residual tumour occurred more frequently with tumours extending far posteriorly because in these cases the placement of scissors posterior to the tumour was prevented by the optic nerve or excessive retinal bulging through the scleral window.

Recurrent tumour from microscopic deposits had an overall incidence of $32 \%$ at 7 years. No cases occurred more than 7 years postoperatively. Recurrence was most common after excision of large, posterior tumours containing epithelioid cells. This was probably because large tumours and those of mixed/epithelioid cell type were more likely to have subclinical tumour extensions than small, spindle cell tumours. Growth of microscopic deposits into visible tumour recurrences may also have been more rapid in the case of large tumours containing epithelioid cells. Tumour extension far posteriorly was of statistical significance probably because it prevented wide clearance margins from being achieved.

Histological assessment of surgical clearance of the tumour was not reliable in predicting local tumour recurrence from microscopic disease. In patients not receiving any adjunctive radiotherapy or photocoagulation, such recurrence occurred in $8 \%$ of 72 patients with apparently complete tumour excision and in only $13 \%$ of 55 patients with incomplete excision. It is interesting that after iridocyclectomy other workers report local recurrence in $3 / 29$ $(10 \%)$ of patients after apparently complete excision and in $12 / 68(18 \%)$ patients with incomplete excision. ${ }^{18}$ These findings suggest that all patients should receive adjunctive treatment if possible irrespective of the histological evidence of clearance.

Comparisons between our data and those published by other workers are of limited significance because of the large number of confounding factors. Shields and associates report an $11 \%$ incidence of local tumour recurrence, 9 but only $6 \%$ of all tumours were located entirely within the choroid compared with $61 \%$ in our sample so that our tumours were more difficult to resect. An evaluation of 107 iridocyclectomies performed by several surgeons showed that 15 eyes (14\%) developed local tumour recurrence and that an additional nine eyes ( $8 \%$ ) were enucleated because of incomplete excision. ${ }^{18}$ In comparison, only two $(6 \%)$ of our patients developed recurrence after iridocyclectomy by the close of the study. Our results, therefore, seem to compare favourably with those of other workers.

We did not achieve statistically significant reductions in the rates of residual and recurrent tumour with ocular decompression or with year of operation. There are several possible reasons for this. Firstly, we probably attempted to resect more challenging cases as we gained more experience. In addition, until we became aware of the results of this study, we were misled (i) by the normal appearances of the choroid adjacent to the tumour when deciding where to place our scissors at surgery, and (ii) by the histological evidence of clearance when deciding whether or not to administer adjunctive treatment. Now, tumours are excised with wider clearance margins and, in addition, adjunctive plaque radiotherapy, laser photocoagulation and/or cryotherapy are applied irrespective of histological clearance. With regard to the management of residual or recurrent tumour, we no longer rely on ultrasonography for the diagnosis of persistent tumour and immediately perform enucleation if opaque media preclude proper examination of the fundus by ophthalmoscopy. In the event of residual or recurrent tumour we are more inclined to perform plaque radiotherapy instead of laser photocoagulation and we no longer rely on fluorescein angiography to assess tumour viability after treatment. ${ }^{19} 20$

In the 46 patients who received adjunctive plaque radiotherapy, the rate of tumour recurrence was significantly lower than in the rest of the patients. This suggests that all patients should receive additional therapy, if possible. The placement of a radioactive plaque at the end of a local resection may be difficult or impossible if the scleral flap is very large or if external plombage has been applied, and may be undesirable if the eye has been filled with gas. Furthermore, radiotherapy may cause radiational optic neuropathy, maculopathy, or cataract. There are other ways of preventing tumour recurrence, such as (a) excising the tumour with wider clearance margins, with the aid of larger scleral openings and greater ocular decompression, and (b) adjunctive laser photocoagulation and cryotherapy. Further studies are required to determine whether such measures would be as effective as adjunctive radiotherapy.

Forty six per cent of eyes with residual or recurrent tumour were enucleated. There were various reasons for this outcome, which included (a) inability to eradicate residual tumour because of diffuse spread to the optic nerve, ciliary body, or orbit, and (b) other complications, such as retinal detachment, which may have been caused by the local resection or by the secondary treatment. Other complicating factors were present in the early years, such as (i) the lack of ruthenium plaque radiotherapy and laser photocoagulation, (ii) inexperience with laser 
photocoagulation and radiotherapy when these techniques were first introduced, (iii) excessive reliance on fluorescein angiography after photocoagulation and on ultrasonography for the detection of residual or recurrent tumour in disorganised eyes, and (iv) lack of experience in recognising early recurrences ophthalmoscopically. As a result, there were several patients in whom the recurrent tumour either was not recognised early, or was inadequately treated, or both, and a number of these patients went on to develop extraocular tumour extension. In another study, we show that bulky local tumour recurrence and extraocular tumour extension are associated with an increased risk of metastatic disease. ${ }^{13}$ It is uncertain whether recurrence and metastasis shared a common cause or whether the recurrence was the source of the metastases; however, patients treated by local resection need close monitoring by an experienced surgeon, with prompt enucleation if adequate ophthalmoscopic examination is not possible because of irreversible ocular disorganisation or if residual disease cannot be treated effectively.

In conclusion, tumour extension to within 1 disc diameter of the optic disc or fovea increases the risk of visible residual tumour after trans-scleral local resection. Such posterior tumour extension is also a risk factor for delayed local tumour recurrence, with other adverse prognostic factors being basal tumour diameter of $16 \mathrm{~mm}$ or more, presence of epithelioid cells, and lack of adjunctive plaque radiotherapy. A histological report of complete tumour excision did not guarantee that future recurrence would not occur. Recurrent tumours were all detected within the first 7 years postoperatively. Persistent tumour tended to become multifocal and to extend extraocularly if treatment was delayed or unsuccessful. The results of this study have prompted us to perform local resection with wider clearance margins, especially in the case of tumours having a diameter of more than 15 $\mathrm{mm}$, and we now administer adjunctive treatment in all patients irrespective of estimates of recurrence based on risk factors and histological evidence of clearance. Patients require close monitoring, preferably by an ocular oncologist or a skilled retinal surgeon, especially during the first 7 postoperative years. Recurrences should be treated aggressively, preferably by plaque radiotherapy unless they are very small and flat, in which case photocoagulation may be adequate. Further studies are in progress to assess the impact of these changes on local tumour control and metastatic disease.

Supported in parts by grants from the Scottish Home and Health Department, 150/799, Greater Glasgow Health Board, the Ross Foundation for the Prevention of Blindness (Scotland), and the Hayward Foundation.

The authors wish to thank all the ophthalmologists who have referred patients to the Ophthalmic Oncology Service and who have returned questionnaires. We also acknowledge the contribution of Professor W R Lee, who performed the pathological examination of the resected tumours.

1 Seddon J, Egan KM, Gragoudas ES. Choroidal melanoma: prognosis. In: Ryan SJ, ed. Retina. 2nd ed. St Louis: Mosby, 1994: 742-52.

2 Lommatzsch PK. Results after beta-irradiation (106Ru/106Rh) of choroidal melanomas: 20 years' experience. Br 7 Ophthalmol 1986; 70: 844-51.

3 Packer S, Stoller S, Lesser ML, Mandel FS, Finger PT Long-term results of iodine 125 irradiation of uveal Long-term results of iodine 125 irradiation
melanoma. Ophthalmology 1992; 99: 767-74.

4 Char DH, Quivey JM, Castro JR, Kroll S, Phillips T Helium ions versus iodine 125 brachytherapy in the management of uveal melanoma. Ophthalmology 1993 100: $1547-54$.

5 Gragoudas ES, Seddon JM, Egan K, Glynn R, Munzenrider $\mathrm{J}$, Austin Seymour M, et al. Long-term results of proton beam irradiated uveal melanomas. Ophthalmology 1987; 94: $349-53$.

6 Bercher L, Zografos L, Chamot L, Egger E, Perret C Bercher $L$, Zografos $L$, Chamot $L$, Egger E, Perret $C$,
Uffer $S$, et al. Functional results of 450 cases of uveal melanoma treated with proton beam. In: Bornfeld $\mathrm{N}$, melanoma treated with proton beam. In: Bornfeld $N$, A, Zografos L, eds. Tumors of the eye. Amsterdam: Kugler, 1991: 507-10.

7 Foulds WS. The local excision of choroidal melanomata Trans Ophthalmol Soc UK 1973; 93: 343-6.

8 Peyman GA, Juarez CP, Diamond JG, Raichand M. Ten years experience with eye wall resection for uveal malignan melanomas. Ophthalmology 1984; 91: 1720-5.

9 Shields JA, Shields CL, Shah P, Sivalingam V. Partial lamellar sclerouvectomy for ciliary body and choroidal tumors. lar sclerouvectomy for ciliary body

10 Damato BE, Foulds WS. Surgical resection of choroidal melanomas. In: Ryan SJ, ed. Retina. 2nd ed. St Louis: CV melanomas. In: Ryan SJ.

11 Damato BE, Paul J, Foulds WS. Predictive factors of visual outcome after local resection of choroidal melanoma. $\mathrm{Br} \mathfrak{f}$ Ophthalmol 1993; 77: 616-23.

12 Damato BE, Foulds WS. Ciliary body tumours and their management. Trans Ophthalmol Soc UK 1986; 105: 257-64.

13 Damato BE, Paul J, Foulds WS. Risk factors for metastatic uveal melanoma after trans-scleral local resection. $\mathrm{Br} \mathscr{f}$ Ophthalmol 1996; 80: 109-16.

14 Todd JG, Colvin JR. Ophthalmic surgery. In: MacRae WR, Wildsmith JAW, eds. Induced hypotension. London: Elsevier Wildsmith JAW, eds. Induced hypotensi

15 Foulds WS, Damato BE. Low-energy long-exposure laser herapy in the management of choroidal melanoma. Graefes Arch Clin Exp Ophthalmol 1986; 224: 26-31.

16 Armitage P, Berry G. Statistical methods in medical research. 2nd ed. Oxford: Blackwell, 1987.

17 Cox DR, Oakes D. Analysis of survival data. London: Chapman and Hall, 1984.

18 Forrest AW, Keyser RB, Spencer WH. Iridocyclectomy for melanomas of the ciliary body: a follow-up study of pathology and surgical morbidity. Ophthalmology $1978 ; 85$ : pathology

19 Damato BE. Why do choroidal melanomas fluoresce on angiography? In: Bornfeld B, Gragoudas ES, Höpping W, Lommatzsch PK, Wessing A, Zografos L, eds. Tumors of the eye. Amsterdam/New York: Kugler Publications, 1991 : 223-30.

20 Damato BE. Tumor fluorescence and tumour-associated fluorescence of choroidal melanomas. Eye 1992; 6:
$587-93$. 
Germany on 2-6 June, 1996. Further details: INTERPLAN, c/o Mr B Lichtinger, Sophienstrasse 1, D-80333 München, Germany. (Tel: ++-(0)89-594492; Fax: ++-(0)89591610.)

\section{Office of Continuing Medical Education}

An update on the management of age-related macular degeneration will take place on 7-8 June 1996 at the Johns Hopkins University School of Medicine, Johns Hopkins Medical Institutions, Baltimore, Maryland, USA. Further details: Office of Continuing Medical Education, Johns Hopkins Medical Institutions, Turner 20, 720 Rutland Avenue, Baltimore, MD 21205-2195, USA. (Tel: (410) 955-2959; Fax: (410) 955-0807.)

\section{International Society of Dacryology}

The IVth International Congress of the International Society of Dacryology will be held in Stockholm on 9-11 June 1996. Further details: Dr G B van Setten, St Eriks Eye Hospital, Fleminggaten 22, S-112 82 Stockholm, Sweden.

\section{The Brian Harcourt Memorial} Symposium

The 7th Brian Harcourt Memorial Symposium will take place on 2 July 1996. The symposium topic will be glaucoma. Further details: Mr Mitchell Ménage, Eye Department, Leeds General Infirmary, Clarendon Wing, Belmont Grove, Leeds LS2 9NS. (Tel: 0113243 2799; Fax: 0113292 6479.)

\section{International Congress New}

Developments in Ophthalmology 1996

An international congress on New developments in ophthalmology' will be held on 29-31 August 1996 in Nijmegen, the Netherlands. Further details: Professor dr AF Deutman/Mrs Y Hennink, University Hospital, Department of Ophthalmology, PO Box 9101, 6500 HB Nijmegen, the Netherlands. (Tel: (31)24 361 5105; Fax: (31)24 354 0522.)

\section{Baylor/Welsh Cataract \& Refractive Surgical Congress 1996}

The Baylor/Welsh Cataract \& Refractive Surgical Congress 1996 will be held at the Hyatt Regency Hotel, Houston, Texas on 5-7 September 1996. Further details: Eula Mae Childs, Cullen Eye Institute, Baylor College of Medicine, 6501 Fannin (NC200), Houston, TX 77030, USA. (Tel: 713-7985941; Fax: 713-798-4364.)

\section{International Symposium on \\ Fluorescence Angiography}

The International Symposium on Fluorescence Angiography will be held at the University of St Gall, St Gall, Switzerland on 8-12 September 1996. Further details: ISFA '96, c/o AKM Congress Service, Clarastrasse 57, PO Box, CH-4005 Basel, Switzerland. (Tel: ++41 61 69151 11; Fax: ++416169181 89.)

\section{British and Eire Association of} Vitreo-Retinal Surgeons (BEAVRS)

The next meeting of the British and Eire Association of Vitreo-Retinal Surgeons (BEAVRS) will be held at the Manor House
Hotel, Morehampstead, Devon on 17-18 October 1996. Further details: Mrs Jill Gledhill, Torbay Hospital, Lawes Bridge, Torquay TQ2 7AA. (Tel: 01803 654825; Fax: 01803 655011.)

\section{2nd International and 4th European Congress on Ambulatory Surgery}

The 2nd International and 4th European Congress on Ambulatory Surgery will be held at the Queen Elizabeth II Conference Centre, Westminster, London on 15-18 April 1997. Further details: Congress Secretariat, Kite Communications, The Silk Mill House, 196 Huddersfield Road, Meltham, West Yorkshire HD7 3AP. (Tel: +44 1484 854575; Fax: +44 1484 854576.)

\section{Correction}

Unfortunately, one of the authors of a letter (Resolution of calcific band keratopathy after lowering elevated serum calcium in a patient with sarcoidosis) which appeared in the November issue of the BfO (Johnston et al, p 1050) was left out. She is Melanie C Corbett, Medical Eye Unit, St Thomas's Hospital, London. We apologise for this omission.

\section{Correction}

Owing to a computer error the wrong graphical material appeared in Figure 1 of the paper by Damato et al (Risk factors for residual and recurrent uveal melanoma after transscleral local resection), in the February issue of the journal (BfO 1996; 80: 102-8). The correct version of this figure is given below.

Figure 1 Kaplan-Meier curves showing the percentage of eyes without recurrent tumour according to tumour cell type. Local recurrence was more common with mixed and epithelioid tumours than with spindle cell tumours.

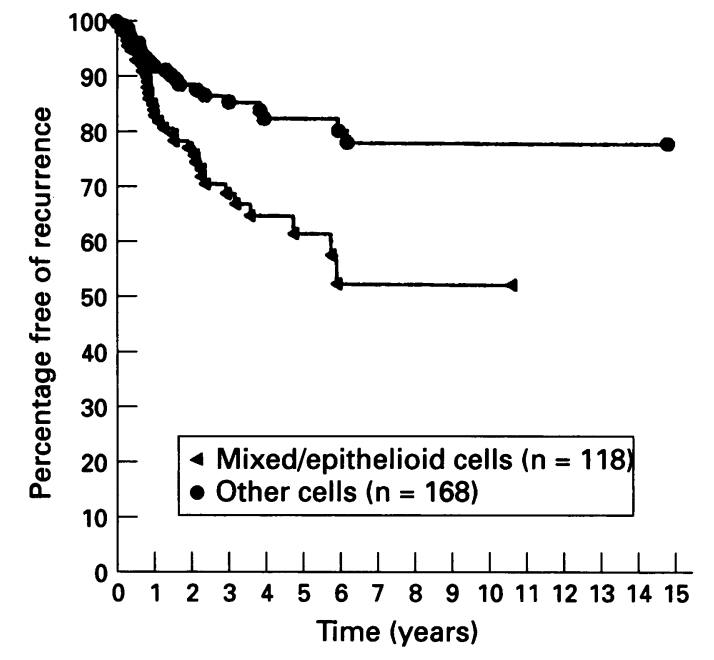

